\title{
Legal regulation of tourism activities in Russia and the CIS countries
}

\author{
Ludmila Spektor ${ }^{1, *}$ and Kostanyan Naira ${ }^{2}$ \\ ${ }^{1}$ Institute of Service and Entrepreneurship (branch) of DSTU in Shakhty, 110, Shevchenko str., \\ Shakhty, Rostov region, 346500, Russia
}

\begin{abstract}
The tourism and hospitality industry produces many social benefits. More specifically tourism creates employment opportunities, contributes to the growth of local and regional economies by improving both the living standards of resident households and the incomes of local firms and represents "a tool for poverty alleviation" especially in developing countries. Nowadays tourism is the biggest industry globally. In particular according to the World Tourism Organization and Organization of American States, "data indicates that the sector contributes to more than $10 \%$ of global gross domestic product and provides for one in ten jobs in the world".
\end{abstract}

\section{Introduction}

Modern tourism is a combination of various types of activities aimed at creating goods and providing services to travelers in order to generate income due to the use of various objects of a natural, historical, cultural and other nature as unique places of display and recreation that differ in the natural and cultural characteristics of a country or region. In the scientific discourse tourism attracts the attention of many researchers: sociologists, economists, marketers, lawyers, and so on, who consider its individual components. At the same time, tourism as a whole is not sufficiently studied as an object of state-legal influence and a subject of legal regulation which has its own unique specifics. In the latter capacity, tourism is "politically significant government decisions" that actualizes the study of the phenomenon of tourism from the perspective of legal-political science and application of its generalizations in the further development of scientific knowledge in the tourism and travel industry practice. Traditionally, the subject of legal regulation is understood as a qualitatively homogeneous type of public relations, which is affected by the norms of a particular branch of law. The subject of legal regulation, along with the method of regulation, acts as a criterion for the division of legal norms by industry due to its objective nature, which follows from the very existence in society of specific relations between people about something. By regulating certain social relations, the law fixes the established social practice, acts as a "powerful organizing factor, brings special certainty and stability to the relevant sphere of public and state life", thanks to which public relations acquire a legal form, becoming legal relations. The progressive development of science and technology, as well as the spheres of public life, leads to the fragmentation of old and the formation of new branches (space, energy law, etc.)

\footnotetext{
* Corresponding author: spektor2@yandex.ru
} 
and sub-branches (promissory note, pledge, stock, etc.) of law, which have their own subject of regulation. At the same time, there is a process of forming complex industries that include several interrelated subjects of legal regulation, such as environmental, agricultural, transport law, etc. Individual authors in their research on the development of industry education, count up to sixty new complex branches of Russian law. It seems that in this case, we can rather talk about branches of legislation that are not built on the subject principle, but from the point of view of the practical expediency of the application of law by state authorities and other subjects. In this regard, the branches of law often "lag behind" the branches of legislation, remaining unchanged for a long time. For example, the legal regulation of relations in the field of tourism forms tourism legislation, while it is premature to talk about tourism law as a branch of law. The legal regulation of tourism is carried out both by national law and by international legal acts.

\section{Methodology}

Comparative legal research. This method was used to compare and characterize the legal status of tourism activities in Russia and the CIS countries. The analysis of the provisions of the current legislation allows us to identify the significance of the legal norm and determine the degree of its influence on the development of tourism activities. Method of interpretation of legal norms. The historical and political method of interpretation helps to reveal the meaning of a legal norm appealing to the history of its adoption, the goals and motives that determined its introduction into the system of legal regulation.

\section{Results of the research}

The norms of international law governing relations in the field of tourism are not codified and are often contained in various documents. A number of international acts form the basis of international legal regulation of relations related to tourism and travel. Article 24 of the 1948 Universal Declaration of Human Rights states that "everyone has the right to rest in his spare time, including reasonable limitation of working hours and periodic paid leave". Article 7 of the International Covenant on Economic, Social and Cultural Rights of 1966 It reflects the obligation of States to ensure the right to "rest, reasonable limitation of working hours and periodic paid leave, as well as payment for public holidays". The principles set out in subsequent international documents of a recommendatory nature - the Manila Declaration on World Tourism, the Charter of Tourism, the Tourist Code and others-emphasize the humane nature of tourism and its importance as a means of improving the quality of life of peoples, an essential factor in strengthening peace and international cooperation. At the same time public relations, being subject to legal regulation, do not lose their properties, remaining spiritual, political, cultural, moral, etc. Part of public relations can exist only in the form of legal relations and function exclusively in this capacity, such as constitutional, administrative, procedural, etc. Some may be of a twofold nature, functioning both as de facto relations between people, organized and regulated by social norms, and as legal relations included in the orbit of legal regulation. Thus, relations in the field of tourism can be both legal and amateur in nature. The latter is inherent in travel and trips that are not subject to special legal regulation, since any citizen or group of citizens has the right to independently visit tourist display objects located in their native city or nearby cities, as well as public natural objects of tourist significance, at their own expense, without contacting tour operators or travel agents. The regulatory role of law in this case is reduced to a system of prohibitions that express the impossibility of committing acts that violate the interests of the individual, society or the state. Thus, in the field of tourism, relations that develop in the 
process of people's relationships and follow from the norms of customs, etiquette or rules of decency are not subject to legal regulation. Tourism was not always in the state's sphere of interest, although it controlled the movement of persons, goods and services not only on its territory, but also when crossing its borders. In the process of developing scientific and technological progress, the emergence of new and more advanced modes of transport (rail, steamship, etc.), the opportunities for travel and travel have expanded, which has led to the need for state control over financial and human resources in the process of their movement. At various historical stages of the development of society and the state, the attitude to tourism has not always been unambiguous. Tourism in the modern sense originated in the Victorian era. Travel and trips made before that, for the most part, were not of a tourist nature. With the fashion for traveling in Europe, which appeared in the second half of the XIX century, the first tourist organizations are actively developing. At the end of the XIX century, tourist organizations appeared in the Russian Empire and the Caucasus and the Crimea became the area of their interests. With the increase in the financial and health components of tourism, states began to strive to expand tourist areas that bring profit through their visits by representatives of both their own people and foreigners. So, in 1915 the First All-Russian Congress on Improving Domestic Medical Areas was held in Petrograd which recognized the importance of state tourism development to stimulate entrepreneurship and attract foreign investment. After the October Revolution of 1917, resorts and other medical and health infrastructure facilities were nationalized. Under the conditions of the Soviet state, tourism became widespread, and as a result, the foundations of its legal regulation were laid. In the first years of Soviet power, numerous decrees were issued aimed at regulating the tourism sector and implementing the right to rest of citizens of the RSFSR. Articles 119-120 of the USSR Constitution of 1936 provided workers with the opportunity to use "a wide network of sanatoriums, rest homes, clubs... a wide network of resorts". In the post-war period, tourist services to the population became one of the socially-oriented activities of the state to ensure the recreational and other needs of citizens. In the 1960s, the state body for the management of foreign tourism was created. Thus, tourism as a socio-historical, socio-cultural phenomenon that exists in society, was perceived by the state as an object of public interest. Over time, a corresponding regulatory framework was created, initially presented only bylaws, but with the collapse of the USSR and the transition to market relations in the economy, it received legislative formalization. Currently, tourism is interconnected with many state, public and private interests and has a significant impact on society (economic sphere, leisure, consumer culture, axiological guidelines, social ties and communications, lifestyle, etc.). Since the consumption of a tourist product is associated with its implementation and the movement of its main purchasers - tourists, the most important for the state are the socioeconomic aspects of tourism and the proper legal regulation of the tourism industry. and its impact on tourism is carried out through state regulation of tourism activities ". At the same time, it should be taken into account that "extensive factors of economic growth have prevailed in Russian tourism for many years". This actualizes the problem of improving the efficiency of using the country's tourism potential, which consists not only in overcoming the existing difficulties inherent in the current moment and having their deep causes in the global economic crisis and the crisis of multiculturalism, but also in the competition in the world tourism market in the context of the globalization of the international tourist space, of which the Russian Federation is a part. These tasks cannot be solved by themselves, but require the consolidation of the efforts of society, the tourism sector and state institutions, including the legislative regulation of tourism as a separate object of legal influence. The developed tourism sector is primarily interested in the middle class, which is able to include the majority of the active population, which has its own standards of consumption. The tourism sector is organically interwoven into the structure of the emerging civil society as a society based on private property, interests, needs and social communication. Civil society institutions are 
ideally designed to serve the implementation of private initiatives of citizens, the disclosure of their potential as creative individuals, which is also characteristic of tourism as a form of recreation and active pastime. The transformation of social interests leads to a greater differentiation of consumption needs, which also affects the tourist preferences of citizens. Such forms of tourism as extreme, business, event, urban, rural tourism are developing, and sports types of tourism, which include not only visiting sports events, but also direct participation in them, are also very popular. This implies an increase in the number of legal ties and relationships both in the formation and in the direct implementation of a tourist product consisting of a set of services. Therefore, the activities of tour operators, travel agents, transport and other organizations engaged in the tourism sector, a wide range of issues arising in the course of their functioning, become the subject of regulation of numerous legal norms. Tourism, being an area regulated by civil, administrative, international, transport and other law, is currently not fully explored in order to become an independent scientific direction. In this regard, we can identify a number of features that can facilitate the growth of this field of knowledge and a better understanding of tourism as a subject of legal regulation: the heterogeneity of tourism as a sphere of social relations, social and cultural phenomenon; the relatively short history of formation and development of the tourism industry; lack of attention to non-economic components of tourism, etc. The complexity of the subject of consideration, since it is multifaceted and, therefore, contains a number of inaccurate formulations, due to the fact that there is still no consensus on the definition of tourism, which is complicated by the conditions of cross-regulation by many branches of law; the fact that tourism, entering the sphere of research of various scientific disciplines, has not yet been subjected to a comprehensive systematic analysis in the context of legal theory, which may be problematic for law enforcement practice, therefore, it is necessary to establish boundaries within which it will be possible to form approaches to the study of it as an object of legal influence. To address these issues, it seems appropriate to use a multidisciplinary approach, the essence of which is to try to integrate a variety of scientific areas and disciplines and concentrate them in the field of tourism studies. In our opinion, the use of this approach in the analysis of the legal regulation of tourism activities will allow us to more fully and systematically consider the legal regulation of relations in the field of tourism, identify their patterns and suggest ways to improve the existing regulatory framework in the field of tourism. At the turn of the century, Russian tourism enthusiasts realized the beauty of nature walks, including at a distance from their place of permanent residence. I wanted to see Valaam, Solovki, Lake Baikal and many other beauty and historical places of my own country. The end of the last century marked the beginning of the development of a new tourist destination. The name of this direction is eco-tourism. The popularity of ecotourism is growing in proportion to the deterioration of the planet's ecology. The uniqueness and vastness of the territory, the opportunity to admire the natural environment in its original form represents great opportunities for the development of this type of tourism in Russia. By order of the Government of the Russian Federation dated 20.09.2019 № 2129-R approved the strategy of tourism development in Russia, which taking into account the specifics of the goal to develop a separate concept of development of ecological tourism 711 in Russian Federation for the period up to 2035. Russia is rightfully considered one of the greenest countries in the world, forests occupy more than $45 \%$ of its territory, and 11 natural sites are UNESCO World Heritage Sites.In connection with the coronavirus pandemic, the introduction of restrictions on entry and exit from the state by most countries of the world, the tourism industry has undergone a significant decline and has become one of the most affected sectors of the economy. It is possible that people's travel preferences may change after the opening of the borders. Once-popular destinations - especially China, Turkey, Spain and Italy-will not be so popular for a while. At the same time, Russia has a chance for a serious development of domestic tourism and the opportunity to redirect at least some of 
the travelers to rest on the territory of their own country. The development of eco-tourism has its supporters and opponents. It is often associated with interfering with and harming nature. However, ecotourism is not just one of the types of outdoor activities. In GOST R 56642-2015, ecotourism is defined as tourism for educational, recreational, and recreational purposes, carried out within the boundaries of specially protected natural areas (hereinafter SPNA), in which the main motivation of tourists is to observe and become familiar with nature in the pursuit of its preservation, having a minimal impact on it. The question of the possibility of using protected areas for mass visits in the Russian Federation is still debatable. Many representatives of the scientific community, the public, and the employees of protected areas themselves believe that this is not compatible with the main goals of their creation improving the state of the environment, preserving the unique natural heritage for future generations. Although it is possible to give examples of other views and real embodiments of the possibility of using protected areas. Ecotourism is based on the desire to find ways to solve the problem of interaction between society and nature. For our country, this is a new direction that requires a completely different approach-both from the side of restructuring the psychology of the population in the direction of educating the traditions of nature conservation, and from the side of state and other bodies that ensure the availability and quality of services provided. When visiting remote unspoilt corners of the earth, a person is reunited with nature, which gives him the opportunity to become better, to understand the beauty and fragility of the surrounding world, and the imminent danger of his active economic activity for the first time.

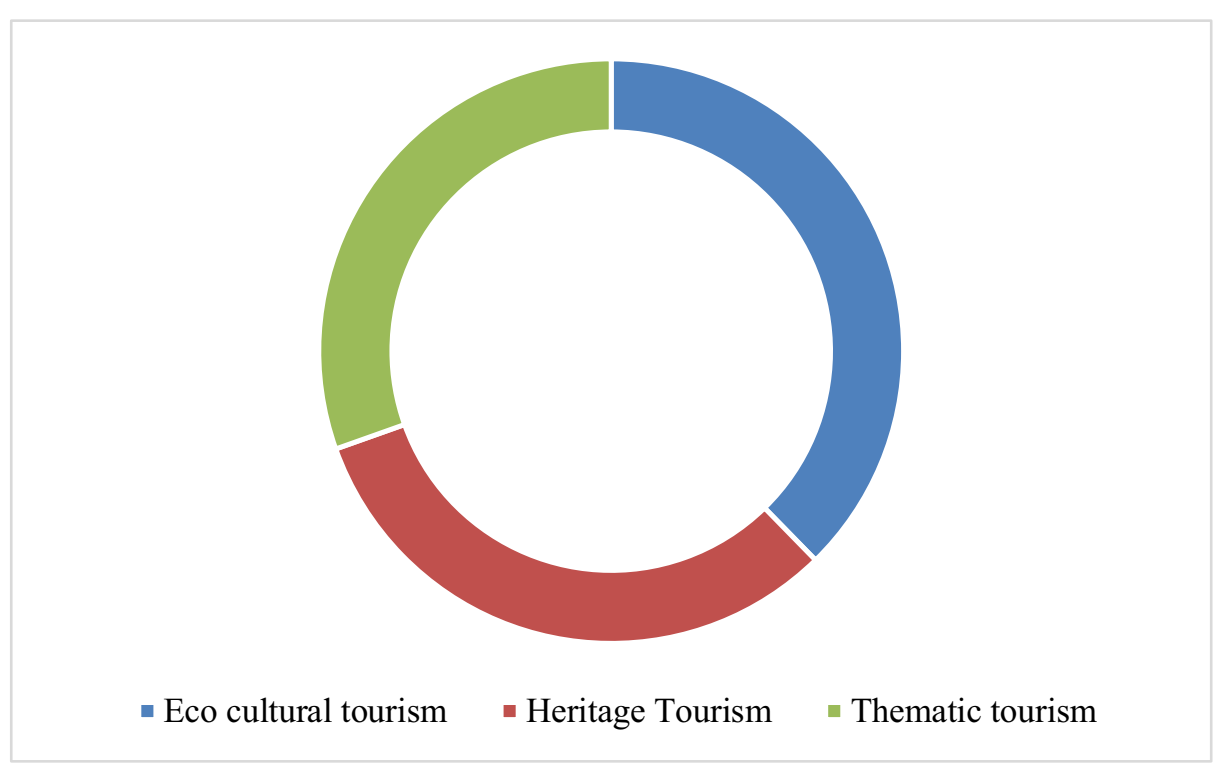

Fig. 1. Types of cultural tourism.

The purpose of organized tourism is to preserve the unique landscapes in their original form and to form people's respect for nature. In accordance with the current legislation, every citizen has the right to use natural objects and resources that are in state and municipal ownership and are classified in accordance with the law as objects of general use. However, not everyone is able to independently organize a vacation in nature: choose a direction, build a route, ensure safety and ultimately achieve the goal and not harm the natural environment. The development of organized eco-tourism is directly related to the creation of new ones and the restructuring of the existing system of specially protected natural areas.According to Roszapovedtsentr today there are 46 about 12 thousand specially protected natural areas of 
various levels and categories in the country. Their total area is 203 million hectares, including land with internal reservoirs - 193 million hectares or $11.3 \%$ of the entire territory of the country. In addition, according to the implementation plan of the federal project for the Conservation of biological diversity and the development of eco-tourism until 2024, the Russian Federation intends to create at least 24 more protected areas. However, if Russia ranks first in the world in terms of the number of lands with the status of special protection, then it is 14 in terms of attendance, and many times lags behind many countries in terms of profitability. As already mentioned, Russia is not a leader in the introduction and development of eco-tourism. However, in this regard, we also have certain advantages - we can organize this activity based on the positive experience of leading international organizations in the field of regulated tourism, which indicates the possibility of providing a high level of service for 6 travelers and preserving the natural balance. In this sense, we can refer to the countries of Europe and the United States, which are in great demand for travel to protected natural areas both within their own countries and outside them. At the same time, every traveler knows about the principles of eco-tourism, which are the expression of unshakable rules of behavior in nature. An important component of the formation of ecological culture is direct interaction with it. In fairness, it should be noted that the fears associated with the possible negative impact of mass tourism on the fragile natural balance of ecological systems are not always unfounded. Awareness of the need for a careful attitude to nature, the motto "do no harm" is not typical of most Russian citizens. However, it seems that the availability of natural and scientific potential of protected areas, provided they are accessible, and at the same time the correct implementation of the goals of eco-tourism in the aggregate will certainly contribute to a rethinking of the attitude to nature, the desire to preserve it. The task of ecotourism for the period of implementation of the concept of ecotourism development is to increase the number of visitors to specially protected natural areas to 16 million people by 2035 . At present, despite the fact that there is a more loyal approach to the possible access of the population to specially protected areas, the flow of tourists has increased slightly. One of the reasons for this is the low popularization, the lack of information about the possibility of protected areas to receive tourists, weak marketing and advertising of environmental objects, which clearly does not contribute to their promotion and recognition in the market. On the territory of any subject of the Russian Federation, there are protected areas with different legal regimes. However, residents, with the exception of those who directly live in such territories, know little about their existence, and if they do, they consider them either closed to the public, or do not correlate with the possibility of recreation on them due to the limited tourist routes, insufficient equipment, and a limited set of recreational services for travelers. More popular are foreign resorts with a well-developed infrastructure, an established system of discounts on the most popular destinations. Another problem is the vast expanses of our Homeland. The opportunity to admire the beauty of Lake Baikal, Kamchatka and the Kuril Islands is not affordable for most citizens due to the high cost of travel and stay on them. In 2020, for the first time, the Government of the Russian Federation approved a program aimed at supporting domestic tourism, including environmental tourism. The state compensates the Russians for part of the costs of recreation within the country. Of course, the increase in the number of tourists should not change the main goal of creating protected areas. It is no accident that in the national project "Ecology" the conservation of biological diversity is in the first place, and the development of eco-tourism is in the second place.

\section{Discussion of results}

First of all, ecotourism is a responsibility. Probably, outdoor recreation does not imply the presence of fashionable, multi-storey hotels, but the time of non-professional construction 
solutions is rapidly becoming a thing of the past, and the demand for high - quality objects, including ecotourism infrastructure, is growing every day. Ecotourism development projects should be based on modern technologies and green innovations. It is obvious that the approach to solving the tasks set should correspond to modern realities. Prohibitions and restrictions should be replaced by dialogue and mutually beneficial cooperation. These are the principles underlying the concept of eco-tourism. It is this interaction that can ensure safe activities in the field of ecotourism for our country's protected areas, and at the same time, such activities can bring tangible income to both the state and entrepreneurs. This, in turn, will ensure a decent advertising of such places, a comfortable and safe stay of tourists and compliance with the principles of respect for the surrounding riches of nature. One of the obvious reasons for the lack of tourist traffic to Russian ecocentres - poorly developed infrastructure-is due on the one hand to the presence of a large number of legislative restrictions on the implementation of economic activities in protected areas, on the other, to insufficient funding from the state 6 and a lack of own funds, including those received for the provision of paid services. In accordance with the Federal Law "6 On Specially Protected Natural Territories", lands with the status of special protection are divided into several categories, depending on their purpose and importance to the state.

Currently, in order to optimize legislation and eliminate artificial obstacles to construction, the Ministry of Nature has developed an official document aimed at reducing the size of buffer zones around protected areas. It seems that in connection with the planned easing, the main infrastructure facilities could be located in buffer zones, taking into account the environmental restrictions provided for them in the current legislation. While ecological trails, bungalows, viewing platforms are other objects that have a minimal impact on the nature inside the territory. Most of the natural objects and resources (subsurface areas, water bodies, forest lands, nature reserves, etc.), due to their special significance for the state and society, are classified as restricted or withdrawn from circulation. This creates certain difficulties for attracting private investment in the development of eco-tourism, despite the enormous economic potential. One of the possible solutions to the problem of maintaining a balance of interests between investors and specially protected natural areas is the use of a public-private partnership mechanism and, in particular, based on the form of ownership of protected areas, a concession agreement. An example of a successful solution of issues indirectly related to the organization of travel is the implementation of major investment projects of cooperation between the state and business - the construction of transport highways, tunnels, passenger sea ports, landscaping territories. Part 1 of Article 7 of the Federal Law of 13.07.2015 No. 224-FL "On Public-Private Partnership" defines the objects of PPP, which include objects used for the organization of recreation of citizens and tourism. However, part 2 of Article 7 of this law prohibits the use of property as a PPP object, in respect of which the legislation of the Russian Federation establishes that it belongs exclusively to state or municipal property or prohibits the alienation into private ownership. ownership or being in private ownership. This contradiction does not always allow us to use the possibilities of the PPP mechanism in solving issues of ecotourism development. The Land Code and Law 19 on specially protected natural territories contain restrictions on the provision and use of such territories, it is necessary to amend the legislation in order to take into account the environmental directions of the development of public-private partnerships. In turn, concession agreements can establish the obligations of investors to preserve territories, which should reduce environmental risks. Often, problems arise at the regional level due to the different understanding and approach of the administration of the subjects and the population to the development of tourism in their territories. According to the Ministry of Natural Resources of Russia, the creation of the reserve will help preserve the "untouched forests of central Russia", biological diversity and develop eco-tourism. Currently, the idea of creating a reserve has not found support either from the regional 
administration or from local residents, for whom living on land classified as protected will create significant restrictions on their use and disposal.

\section{Conclusions}

First of all, the project declares the preservation of the environment — rare animals and plants, but the theme of the development of eco-tourism is not something that is not hidden - it appears clearly and clearly. It appears that in each case the possibility or necessity of the organization of the reserve or national Park, depending on your goals must be scientifically justified and discussed as widely as possible including arrive at a compromise between the interests of residents designated areas and the development of organized tourism. It is necessary to develop clear criteria that will make it possible to apply to a particular site a protected regime with all the necessary restrictions, and make everything else accessible to visitors, for the development of recreation and tourism. Do not forget that eco-tourism is not only an ecological, but also an economic direction, implying the development of the regions. A well-thought-out, scientific-based development of eco-tourism can become the starting point of socio-economic growth for the local population. Successful promotion of this direction requires a comprehensive approach of the state, including the improvement of the legal framework, the involvement of the business community in the creation of the infrastructure of protected areas, effective partnership with local authorities, taking into account the interests of the population living in territories with the status of special protection. And only an alliance of protected areas with a huge scientific base on the ecology and nature management of the territories entrusted to them, and professional designers can lead to the implementation of projects that will be truly in demand by the population and will lead to the formation of the Russian ecotourism industry. Thus, we can state that the development of eco-tourism in our country is a necessity. The development of this industry will first of all give our citizens the opportunity to get to know their homeland, to visit places in their country that they did not even know about, and to look at Russia with different eyes. At the same time, a competent approach to the development of ecotourism will lead to the financial filling of certain budget items that can be used for the benefit of the nature of our country. At the same time, first of all, it is necessary to seriously improve the legal framework of both legal relations in the field of ecology and environmental objects, and in the field of eco-tourism.

\section{References}

1. M. Bengtsson, T. Raza-Ullah, V. Vanyushyn, Industrial Marketing Management 53, 1930 (2016)

2. A.F. Chim-Miki, R.M. Batista-Canino, International Business Review 26(6), 1208-1217 (2017)

3. M. Damayanti, N. Scott, L. Ruhanen, Annals of Tourism Research 65, 25-35 (2017)

4. V.H.I. Fong, I.A. Wong, J.F.L. Hong, Tourism Management 66, 244-262 (2018)

5. K. Storbacka, R.J. Brodie, T. Böhmann, P.P. Maglio, S. Nenonen, J. Bus. Res. 69(8), 3008-3017 (2016)

6. C. Simone, S. Barile, M. Calabrese, Land Use Policy 72, 493-502 (2018)

7. M. Saviano, P. Di Nauta, M.M. Montella, F. Sciarelli, Land Use Policy 76, 290-299 (2018)

8. M. Saviano, M.M. Montella, Bridging Theories, Strategies and Practices in Valuing Cultural Heritage (Eum, Macerata, 2017) 
9. B. Purvis, Y. Mao, D. Robinson, Sustain. Sci. 14(3), 681-695 (2019)

10. V. Kumar, Anita Pansari, J. Mark. Res. 53(4), 497-514 (2016)

11. P. Jones, M. Wynn, Int. J. Contemp. Hosp. Manage. 31(6), 2544-2563 (2019)

12. E. Jaakkola, L. Aarikka-Stenroos, Ind. Mark. Manage. 80, 27-42 (2019)

13. M.W. Islam, L. Ruhanen, B.W. Ritchie, J. Hosp. Tour. Manag. 37, 97-106 (2018)

14. J.H. Heslinga, P. Groote, F. Vanclay, J. Tour. Fut. 3(1), 23-38 (2017)

15. J.L.H. Bowden, V. Luoma-Aho, K. Naumann, R. Brodie, L. Hollebeek, Customer Engagement: Contemporary Issues and Challenges (Routledge, Singapore, 2016) 